\title{
Dance and somatic education in primary school: a study on discipline with teachers in southern Brazil
}

\section{Maria Fonseca Falkembach \& Gilberto Icle}

To cite this article: Maria Fonseca Falkembach \& Gilberto Icle (2020): Dance and somatic education in primary school: a study on discipline with teachers in southern Brazil, Research in Dance Education, DOI: 10.1080/14647893.2020.1764923

To link to this article: https://doi.org/10.1080/14647893.2020.1764923

\section{Published online: 13 May 2020.}

Submit your article to this journal $\pi$

山 Article views: 16

Q View related articles ¿

View Crossmark data \lceil 


\title{
Dance and somatic education in primary school: a study on discipline with teachers in southern Brazil
}

\author{
Maria Fonseca Falkembach (iD) and Gilberto Icle (iD ${ }^{\mathrm{b}}$ \\ aCentro de Artes, Universidade Federal de Pelotas, Pelotas, Brazil; 'baculdade de Educação, Universidade \\ Federal do Rio Grande do Sul, Porto Alegre, Brazil
}

\begin{abstract}
- The following paper seeks to show how Somatic Education is a usual practice in the classes researched and, at the same time, how it places the body in places of dispute at schools. Notions present in the classes studied such as, for example, the relationship between surveillance and silence and between the latter and listening are thus analysed, among others. This text derives from a study with dance teachers developed in southern Brazil. It describes the research methodological design with ethnographic inspiration, focusing on the work of one teacher in particular. From these elements and from Michel Foucault's philosophy, the article discusses the role of dance in school, especially regarding the tension between the disciplinary culture of Primary Schools and somatic education of listening bodies. Finally, it shows how the conduct of the teacher engenders an artistic conduct, that is a conduct that models school technologies and creation itself. In this way, we present the idea an ethics-oriented morality, opposed to disciplined bodies, over the code at schools.
\end{abstract}

\section{ARTICLE HISTORY}

Received 7 June 2018

Accepted 29 April 2020

\section{KEYWORDS}

Dance; school; somatic education; primary education; dance education

\section{Introduction}

Observing how six teachers lead their dance classes in southern Brazilian schools, it is possible to identify that there is a significant misalignment of dance practices with disciplinary technology and disciplinary knowledge. This misalignment produces a tension that reveals government technologies derived from the school and from the dance practices themselves. We believe that this tension is an effect of the somatic education composing the dance practices.

Dance teaching is recent in Brazil, if considered as a mandatory component of the Arts subject in primary education. ${ }^{1}$ As a result, there are few recent researches on this theme (Gehres 2008; Souza 2015; Cazé and Flávia 2014; Maçaneiro 2008; Corrêa and Santos 2020). None of them, however, focuses on dance teaching as government technology, which produces subjects of a given type (Falkembach and Icle 2016), concerning which subjects, which bodies, which modes of being are produced in dance lessons at schools.

CONTACT Maria Fonseca Falkembach mariafalkembach@gmail.com @ Rua Coronel Alberto Rosa, 62 - Pelotas, Rio Grande do Sul, Brasil, CEP 96010-770. 
This article presents data from an investigation conducted with six primary school dance teachers on the state school system, characterised by a complex social context of poverty and lack of resources. ${ }^{2}$

This research uses the production of French philosopher Michel Foucault as inspiration and tool to analyse the practice of dance at schools. From the perspective, we believe that such government technologies are modes of production of subjects. According to Garcia (2001), the educational act is a government technology, '[...] the way in which the conduct of individuals or of groups might be directed, [...] modes of action, more or less considered and calculated, that were destined to act upon the possibilities of action of other people.' (Foucault 2010, 288). Considering that the object we know is produced by the way in which we know it, the body-subject produced at schools emerges from our modes of conducting practice. Asking what bodies-subjects are being produced in the dance practices is also asking how the teachers conduct their students to the field of knowledge of dance.

Somatic education is placed as subject matter, as it is reported in the interviews of the researched teachers to be one of the main references for dance classes. This is easy to understand, when considering that the somatic approach is assigned an important space in undergraduate courses for dance teachers in southern Brazil (Rosa 2016).

This article is informed by engagement with a number of key questions; these include: why is it difficult to establish a dance practice from the perspective of somatic education in schools? How do the teachers conduct their students to the state of listening, one of the premises of somatic education? How do dance practices derived from uncertainty and from sensation as a mode of knowledge are arranged with school knowledge and technologies?

We will thus show that the difficulty felt is an effect of the tension between different technologies, of the incompatibility between their operations. As disciplinary technology is not dissimilar to other school contexts, we believe this research could contribute to the reflection on (dance) education in different cultures.

\section{Methodology}

From the central research question - how do teachers conduct their students in the field of dance? - we employed a methodology with ethnographic inspiration. We accompanied six teachers in their daily practice at school, for two weeks each, through foundations of Performative Ethnography. The main criterion of choice of the teachers was their interest in engaging in the research. In addition, we adopted the following criteria: the cities with the most teachers and one municipal and one state school in each city. The field research happened between August and November 2015.

Elyse Pineau $(2002,46)$ describes Performative Ethnography as a qualitative case study 'of detailed observation of physical bodies in action within particular classrooms and critical analysis of the social codes articulated by those bodies'. This method adds to the qualitative case study the performance ethnographers' skill which is to be 'able to attend to the embodied particularities of the research situation' (47). Thus, we conducted a participative observation, and in some cases actively participated in the classes observed. All observations were recorded in a notebook, as well as in photographs, video and audio recording. 
We also conducted interviews with the teachers and one staff member of each school management team. In the first encounter with each teacher, before attending the first class, we presented the research proposal and the investigative process, and performed a semi-structured interview. The purpose of this interview was establishing a first contact, starting the dialogue and identifying the teacher's references about dance and education. A second interview, also semi-structured, was held at the end of the process, with questions adapted for each teacher, based on the observation of their classes.

A single data file was prepared for each teacher, in chronological order of production of data, which we named Dossier. Each document contains the transcript of the videos and audios from the classes, the transcript of the interviews and our personal notes in the field log. The files produced in this step are confidential and indicated in the bibliographic references as Dossier plus the fictitious name of the interviewees (to ensure their anonymity). The Dossier were analysed based on the theoretical tools of Michel Foucault (Fischer 2001). Thus, roughly speaking, the topics presented here emerged from this analysis.

This article focuses on the research data produced with teacher Samara (pseudonym), complemented by the interview made with teacher Rita (pseudonym). Samara works in a municipal school in Porto Alegre. The school is located in a poor neighbourhood and most of children live in a vulnerable situation, including cases of violation and drugs at home. The teacher has an undergraduate degree in Dance Education from 2005, and has worked in schools of the municipality since 2007, being in this school since 2011. She chose to stay at this school because of its project 'Escola Preparatória de Dança' (Preparatory Dance School) created by the Secretariat of Culture of the City Hall, under which an exclusive room was designed for the dance classes, a peculiarity of that school, it is a rare situation in Brazilian schools having a dance room. The dance project takes place in the mornings and, in the afternoon, the room is fully occupied with the dance classes of the mandatory curriculum. She teaches groups from the three years of the first cycle (students between six and eight years old), which correspond to the first years of primary school. Three groups are from year 1, another three groups are from year 2 and one group is from year 3; 2 hours per week with each. In addition, she works with one preschool group (five-year old students) one time a week. With an average of 28 students per group, Samara has in total about 240 students.

\section{Between dance and discipline: the place of the body in schools}

Dance practices produce tension in schools, placing the body as the centre of the curriculum, appearing as locus of disputes and discursive investment. Teacher Rita talks about being a dance teacher:

What makes me a dance teacher? [...] the fact I work with the body, obviously. Or not, right? Because you can work with dance and not emphasize this, and not assign it importance, focusing on the steps only, and not on the body itself, on the relationship with others. I give a lot of priority to this in my work. [...] And another thing that makes me a dance teacher ... is this, believing in what I do. (Dossier Rita 2016, 66)

Rita points to the centrality of the body in dance classes, warnings that this is not the body of the motor function discourse, where dance steps are learned through encoded 
movements, to the development of motor skills. The body that she presents in her classes is the body that lives, a cultural body, relational body. Apparently, this is an obvious idea. However, the use of this conception of body in dance classes in schools is not as obvious, because dance knowledge is mistrusted by the school system as a valid knowledge. Such point of view is testified by the principal of the school where Rita works, who classifies dance lessons as 'a very different proposal' (Dossier Rita 2016, 69), compared with math classes:

The students are used to a certain kind of class. And then they watch another kind of class. And then they conclude that isn't a class. [...] It's a tough age to control, even during math classes, which they are afraid of. [...] Imagine during a class that has such a, let's say, different proposition. [...] I think sometimes the teacher has difficulty in getting them to understand her proposition, [...] I believe they somewhat disregard the seriousness of her class, her proposition. That there even is a proposition. (Dossier Rita 2016, 70)

Because the school does not understand the knowledge developed in dance classes, it does not consider it to be school knowledge. The school's principal does not comprehend the pedagogic proposal of the dance teacher, understanding it as lack of seriousness and absence of pedagogical intention.

Knowledge, here, is understood from the perspective of Foucault $(1972,182)$, as a '[...] group of elements, formed in a regular manner by a discursive practice'. Castro synthesises Foucault's definitions of knowledge as:

1) that which one can speak of in a discursive practice (the domain of objects); 2) the space in which the subject may take up a position to talk about objects (subjective positions); 3) the field of coordination and subordination of statements, in which concepts appear, are defined, applied and transformed; 4) the possibilities of use and appropriation of discourses.

(Castro 2009, 394)

Thus, knowledge is understood as a set of rules that allow a particular field to accept or interdict a particular knowledge. One of the effects of mistrust about the knowledge developed in Rita's classes was the installation of surveillance cameras in the dance practice room, as testified by her two months after the interview with the principal. Rita said:

Do you know that dance room? There are cameras over there now. And they [the staff team] don't respect the class. If they see something that they interpret as provocative, they invade my class and give warnings to the students. In summary: I don't teach classes at the room with mirrors anymore. Only if it's a rehearsal and everything is more or less ready. But I no longer use that space for the creation process. I teach in an ordinary classroom. I keep the groups there and teach my classes. The students sweep, they help in the organization and I teach my classes in the classroom. And if it's a class that doesn't need to use the floor, I carry out the activities in the yard. (Dossier Rita 2016, 80)

The dance practices in the school environment act over the disciplined school body, destabilizing its production technologies - naturalised at school - which differ from those of dance bodies. To understand these differences, we identified and analysed three sets of practices: 1) composition practices that are largely based on Laban's studies; 2) practices developed from the perspective of somatic education; 3) practices that involve touch.

The conceptions of body and pedagogical approaches inherent to these practices are not congruent with the surveillance operations impregnated in spaces and over bodies in 
schools. They also differ from the school system of rules and code of normalisation of disciplinary technology. Additionally, they are based on a dimension of experience different from that which seeks the usefulness of actions and bodies. ${ }^{3}$ Surveillance is one of the operations of disciplinary technology (Foucault 2004). This operation is allied to the operation of normalisation. The bodies are surveyed to follow the norm. The institution establishes what is normal, producing behaviours in convergence or deviation to the norm.

In this article, we focus on the second set of practices, developed from the perspective of somatic education. They are practices that take into account sensation as a mode of knowledge, developed in first-person perception: each one's minute observation of their own moving bodies. We noted, in the teachers' classes, traces of the relationship between dance and somatic education, for example, when they begin not in front of the mirror, but on the floor, with eyes closed -, therefore, not with a posture built from an external look, but based on the feeling of each person over their body, over the connections between their joints, through the perception of tensions and of the particular structure of each individual body, leaving the connections free to produce mobility. We identified signs of this relationship when the dance state is built from listening, rather than from a sequence of movements.

We showed how these practices, which are very important in the work of the researched teachers, clash with school technologies, especially with discipline.

\section{Dancing silence: possible displacement of the surveillance operation}

In a research conducted with students from an undergraduate program in dance, Fortin, Vieira, and Tremblay (2009) identify the discourse of somatic education as marginal, in contrast to the dominant discourse of dance training, which fantasises an ideal body. According to the authors, '[...] dance is usually a site where the subject has been traditionally objectified' (49). Diferently, the somatic perspective reduces the emphasis on the external form of dancing bodies and counteracts hegemonic practices, characterised by technical virtuosity, competitiveness, models from the media and the cosmetic industry. The dominant discourse, produced by dispersed statements, is widespread primarily in the television media, reaching also schools.

However, certain principles of somatic education are present in the classes of all researched teachers, in different ways. We do not mean to say that somatic techniques are applied during the classes, nor that somatic education can be applied in a generalist manner. Despite these techniques having similar premises, Ciane Fernandes (2015) points out that somatic techniques have their own unique specificities, demanding time and dedication to master each one of them. In this article, we focus on the analysis of two lessons of teacher Samara, which are emblematic to illustrate such principles: body awareness and listening. We show how dance teachers have displaced the dominant discourse of dance by applying somatic education principles to dance lessons at school.

The Foucauldian perspective understands the subject as an effect of discourses, produced by power relations (Fischer 2001). The ties inherent to the relations between power and knowledge manifest themselves in practice. It is in the process of establishment of these ties that a particular type of subject is produced, that is, a particular type of subjectivity is produced. These ties are discourse. 'Subjects are effects of discourses, and 
these effects - produced inside numerous and specific institutional, social and economic relations - do not exist elsewhere but in the body' (Fischer 2001, 218). Thus, when opposing hegemonic dance practices, understood as components of the dominant discourse, the teachers are opposing the hegemonic idea of subject in dance practices.

The virtuous and competitive body of dance is congruent with the docile body of disciplinary technologies (Fortin, Long, and Lord 2002), as it is also an effect of operations of surveillance and examination, and relies on normalised and idealised standards. There is evidence of the relationship between disciplinary technology, specifically surveillance, and the teaching of dance while emphasizing the external form of the body in Tanya Berg's research (2015). The author researched the changes in behaviour and pedagogical approach of three teachers (herself included) of a dance studio, after the installation of surveillance cameras in the classrooms. Berg claims that with the presence of cameras and screens that broadcast live images (in the waiting room and the office) to a hidden audience, the teachers' external and self-control caused them to become more authoritarian and more concerned with corresponding to the parents' expectations, '[...] moving studio teaching practices away from a feminist pedagogy which values students' voices' $(2015,241)$. The author recognizes that the panoptic operation decreased her sensitivity to the students' reactions and needs. We thus understand that this operation decreased her listening attitude. The author also points out that when under surveillance, the teachers focused on efficiency, giving less space to risk and uncertainty and, in our view, giving more space to the reproduction of standards from the dominant discourse.

In schools, the contraposition to hegemonic dance practices meets the contraposition to the disciplined school subject. This appears in a specific lesson given to a preschool group (with students from 5 to 6 years old) by teacher Samara. When she arrived at the classroom to take the students to the dance room, the lead teacher suggested she used a higher tone of voice that day, because the children were making a lot of noise and were not listening. However, Samara led the class differently and said to the children:

Teacher Samara loves dance and music, but she also loves Silence. Did you know we can dance silence? Did you know we can dance without music? Didn't you? Who did? Do you want to watch me dance in silence? [...] If you become silent I will join the circle and will dance in silence. Then, after I dance in silence, one of you will take my place and continue dancing in silence. Then another, and another, and even when asking to dance in silence, you have to do so with your body. Raise your hand, then you may go, but in silence. (Dossier Samara 2016, 27-28)

Samara was building, in this way, silence as an element of the space to be danced, different from silence as a disciplined body's attitude while waiting for its turn.

Dancing silence disassociates dance from music, changing focus to bodily relations, to the body's materiality. Instead of translating or transposing the characteristics of a particular song to the body, dancing in silence implies the creation of movements based on ways to articulate the body's elements. Silence, then, is established by the listening state of the body, by the attention given to the possibilities of body movements.

In this case, silence is not produced by the outside perspective which controls those who are making noise, but by the need of first-person observation.

The displacement of the way of looking at the body produces the object of knowledge, that is, the soma. According to Hanna, 
When a human being is observed from the outside - i.e., from a third-person viewpoint the phenomenon of a human body is perceived. But, when this same human being is observed from the first-person viewpoint of his own proprioceptive senses, a categorically different phenomenon is perceived: the human soma. (Hanna 1991, 31)

Two distinct modes of viewpoint created two distinct objects. The soma is different from the body and, more than that, it is different from the disciplined body. The perception and production of the soma is radically different from the operation of surveillance.

A disclaimer is needed here. Hanna's theory is based on the idea of the soma as an observed phenomenon that exists a priori. From the Foucauldian perspective, however, the soma is, more than that, a production of the set of rules in which it is inserted, the product of a discourse. In addition, the notion of visibility is also relevant to this matter, it being '[...] any form of sensitivity, any perception device. Listening and touch in medicine, examination in pedagogy, systematic and systematised observation in any disciplinary apparatus, the disposal of bodies in punishment rituals, etc' (Larrosa 2002, 60). Jorge Larrosa gives examples of how Foucault analyses different modes of view related to objects that are seen. There is reciprocity between the way of seeing and what is seen, they determine each other. 'In Foucault's works, both the object and the subject are variables of visibility regimes and depend on their conditions. A visibility regime composed of a specific set of optical machines prepares the object for being seen and, at the same time, the observer for seeing ${ }^{4}$ (Larrosa 2002, 61). A visibility regime produces the object that one knows and, at the same time, the subject of knowledge. 'Therefore, subjects are a function of visibility, of the devices that make them see and which guide their look. And these are historical and contingent' (62).

The perspective of somatic education produces the way of seeing, which includes how knowledge is constructed, that is, from first-person perception, through specific operations. It also produces a certain type of knowledge (a consciousness of and in the body); the object of knowledge (the soma); and also the subject of knowledge (the one whose conduct is leaded by her first-person perception).

In somatic techniques, movements are typically guided by vocal commands with no references of the teacher's body and movements. In this way, the practitioner can direct his/her attention to his/her own body, in contrast to self-perception through a mirror image naturalised in dance classes, which produces self-surveillance.

\section{Between discipline and ethics}

For the practices analysed, the necessary condition for the establishment of the dance state was the creation of body connections. This connected body state occurs from a keen state of attention: the state of listening, one of the premises of somatic perspective (Green 2002). The state of listening is necessary in the silence dancing class described above.

In this class, we may note the difference between the conduct of the lead teacher and teacher Samara's. The former tries to follow the rule of the silent body, that is, she understands silence as an effect of the disciplined body, which in turn is understood as normal. ${ }^{5}$ The latter displaces the focus on the rule itself and proposes that silence emerges from the relation/connection of each individual with his/herself and others.

When working in the production of this kind of silence, Samara also resorts to disciplinary techniques and to the silence of the docile body. Therefore, sometimes, the 
two overlap. Occasionally she explicitly asks students to be as silent as in the classroom. Or instead, she playfully says: 'And to start the exercise of listening to our bodies and to what we're doing here at the dance room, we will now zip up our lip' (Dossier Samara 2016, 88). The teacher plays with different strategies. To do so, she exercises her own listening. The teacher's state of listening produces another way of being in the class, different from discipline.

Samara oscillated between the two different conducts. She also made conscious use of disciplinary strategies. At one point of the interview, she talked about the need of the students' relationship with rules.

In many moments I try to raise the issue of discipline and limit, which are also very important in dance, and which many do not have at home, no father or mother to teach them limits through guided education ... they feel the lack of it and challenge us to trigger this sensation: someone likes me and is telling me, imposing something on me for my own good. (Dossier Samara 2016, 65)

Samara's report impels us to revisit the notion of education as government, that is, as specific ways to conduct the conduct of individuals - which implies conducts (both of whom conducts and of who is conducted) in relation to rules and prescriptions. Firstly Samara associates limits with discipline, then she associates limits with 'guided education'. We believe Samara's two ways of describing limits are not unequivocal.

This difference relates to the distinction that Foucault $(1998,29-30)$ proposes between a code-oriented morality and an ethics-oriented morality. But it is also relates to the school's specific moral-operating mode: disciplinary technology.

According To Foucault, 'Every morality, in the broad sense, comprises the two elements [...], codes of behaviour and forms of subjectivation' $(1998,29)$, which are not disassociated. The moral code, or simply code, is '[...] a set of values and rules of action that are recommended to individuals through the intermediary of various prescriptive agencies such as the family (in one of its roles), educational institutions, churches, and so forth.' (26). The forms of subjectivation, or forms of moral subjectivation, are the way in which the individuals relate to the rules, the process to become their own behaviour according to the rules established, and constitute themselves in this relationship as moral subjects.

When the process is 'code-oriented', there is no room for inventing the way to relate to this code.

The main emphasis is placed on the code, on its systematicity, its richness, its capacity to adjust to every possible case and to embrace every area of behavior. With moralities of this type, the important thing is to focus on the instances of authority that enforce the code, that require it to be learned and observed, that penalize infractions; in these conditions, the subjectivation occurs basically in a quasi-juridical form, where the moral subject refers his conduct to a law, or set of laws, to which he must submit at the risk of committing offenses that may make him liable to punishment. (Foucault 1998, 29)

When the process is 'ethics-oriented', the possibilities of construction of this process are multiple: the ways for individuals to shape their own behaviour according to the rules are multiple.

Moralities in which the strong and dynamic element is to be sought in the forms of subjectivation and the practices of the self. In this case, the system of codes and rules of 
behavior may be rather rudimentary. Their exact observance may be relatively unimportant, at least compared with what is required of the individual in the relationship he has with himself, in his different actions, thoughts, and feelings as he endeavors to form himself as an moral subject. Here the emphasis is on the forms of relations with the self, on the methods and techniques by which he works them out, on the exercises by which he makes of himself an object to be known, and on the practices that enable him to transform his own mode of being. (Foucault 1998, 30)

Based on this, we interpreted the idea of limit in teacher Samara's report: teaching limits would be introducing the code of behaviour and conducting individuals towards a conduct that complies with this code; having limits, or being aware of them, would be to constitute themselves as subjects of moral.

We can infer from this that discipline is a type of technology of production of limits, which conducts to the code in a specific manner and from which subjects become connected to it in a specific way. As disciplinary institution, when school refers to these limits, it is probably associating them with discipline, therefore, with a code of normalisation.

How, then, do individuals become connected to the code in disciplinary technology? Through docility of the body, obedience, self-discipline (self-surveillance and selfexamination), for them to become useful, efficient, normal, as a process of normalisation (Foucault 2004). We believe that, generally, this kind of moral production is codeoriented.

We understand that when Samara associates limits with 'guided education', she refers to another way of conducting towards the rules, which tend to be more flexible. Rules that adapt themselves - not in the sense where individuals can adapt the rules to benefit from them (flexible rules can lead to this), but in the sense of taking care of themselves and others and in relation to life power. We perceive this as an ethics-oriented morality. It is this sort of limit that is produced when listening is summoned.

Samara, in this way, evokes these two modes of moral construction in her report: two types of limit that produce different bodies-subjects. One limit relates to disciplinary technology, whereas the other relates to listening, which is a premise of somatic education. Two types of limits produce two forms of silence: a silence produced by the codeoriented morality and another produced by the ethics-oriented morality.

Deleuze $(1988,41)$ uses the notion of form to talk about that which cannot be put into words and which is also constituted in discourses - initially referred to by Foucault as non-discursive practices. According to the philosopher,

Form here can have two meanings: it forms or organizes matter; or it forms or finalizes functions and gives them aims. Not only the prison but the hospital, the school, the barracks and the workshop are formed matter. Punishment is a formalized function, as is care, education, training, or enforced work. (Deleuze 1988, 43)

Here, dance practices are understood as forms, which delineate and organise matters, assigning them goals. That which form produces is also form, a sort of enunciation of the former. For example, somatic practice is a form that delineates matter in the production of the soma, which is its enunciation. We prefer to call it idea-form instead of content form, according to Deleuze, for whom form would be the prison and content, the prisoner (or, in this case, form would be the school, and students the content). Idea- 
form alludes to the notion that school and student are mutually conformed. It relates to a set of practices involved in the production of a type of subject. One type of idea-form derives from a specific type of limit. Another type of idea-form is created in the arrangement of different types of limits.

If there is another silence, there is another silent body. If the way of listening is different, the silence produced is different. It is a way of listening that produces other types of bodies, different from those produced by the discipline's way of 'looking'.

If the silence of discipline stems from the silent body, in listening, silence is produced by an attitude that is more akin to disquieting, to caring for the self. The silence of listening is the silence of an intense and powerful body.

\section{Listening as ethics}

Listening with the body is being here-and-now, in a state of awareness, ready to react and perceive what is going on at every moment, in my body and in the body of others. Jussara Miller (2007) summarises the Klauss Vianna Technique as a practice of 'body listening', which is how the book in which the author presents the systematisation of this somatic technique is named.

Body listening is one of the principles of the Klauss Viana Technique: an observation of the movement inside the body, carried out so that movements are externalised with individuality, tracing a path from the inside out, aligned with those from the outside in and from the inside in, creating a network of perceptions. (Miller 2007, 18)

The dance that works on this principle described by Miller - that we find in other somatic techniques - produces a body in the state of listening. We understood that teacher Samara works to achieve this state of listening in her students' bodies. In the state of listening, crosstalk with one's peers and their judgment cease, so that attention may be paid to one's own movements, bodily organisation, breathing and bone connections.

In another class, with a group of second-year students (students between 7 and 8 years old), Samara clearly tries to transform the usual modus operandi of classes, referred to by her as 'the old method of choice,' in which she chooses (usually those who are behaving as agreed) and points to who will be the next to join the circle. The transformation that she proposes has great proportions, because it is about turning away from a disciplinary strategy (those chosen to participate are the disciplined bodies) to develop the activity together with the group in a state of silent attentiveness, negotiating through listening. The quality of the class changes. Students engage in this new method, although they create different strategies to organise themselves. They cannot carry out the negotiation in complete silence, part of it is done verbally, but that does not hinder the progress of the game and they can compose the practice without the need for the teacher to define sequel, space and time at all times.

A sum of different operations and commands produced the state of listening in this class: the teacher's state of listening; focus on breathing while making the movements; concentrating on the imaginary connection of the ischium with the ground and of the soft spot with the stars; creation of movements from images. At one point, a student lost focus and started singing the 'song of the big bad wolf. His action was immediately incorporated into the proposal that was being developed: 
The wolf, like the cat and the dog, has a tail, and to move, it uses the head-tail relationship, ${ }^{6}$ which is similar to the relationship between the ischium and the soft spot. This lead to the idea of joining the circle with a movement from the head. In one of the moments of the students' loss of focus, Samara joined the circle with head-tail movements, showing the importance of listening. She showed how she was attentive to everything while dancing, because the wolf has big ears and listens very well. (Dossier Samara 2016, 60)

That which at first had no relationship with the proposal was incorporated into the game. The 'big bad wolf, which initially seemed to disrupt the class, in a student's attempt to call attention to himself, became the trigger for the development of the proposal. Instead of reprimanding the student for not behaving as expected, the teacher understood his contribution as material for the class' composition. There is, thus, a displacement of disciplinary conduct: that which could be disregarded as indiscipline becomes creative material.

The 'wolf body synthesised body connections and the state of listening necessary for the class, which is described below:

The first four students move to the centre of the circle, focusing on the top of their heads. All the others in the circle watch carefully, waiting until the last one gets out of the circle, very slowly, never losing the focus on the head. Four others enter the circle, moving while focusing on the top of their heads. Samara asks for students to trigger the "tuquezinho" in their ears, so they may listen (tuquezinho was a word created impromptu, which refers to the idea of ample listening, the image of a big ear similar to a wolf's, which listens better than human ears). (Dossier Samara 2016, 60)

Being in a state of listening is also being in a state of readiness, when students trigger the 'tuquezinho' in their ears to know the time to enter. The 'tuquezinho' allows listening with the whole body and moving through its connections: of the first vertebra with the spine, and of the spine with the coccyx. At the same time, it develops body awareness, the proprioceptive perception of this connection and of the shapes the body draws in space from the mobility of its bone structure. Being in a state of listening is negotiating, at all times, movements and relationships (between parts of the body, and between bodies) in the composition of practice.

At the same time, the state which the students arrived at in this class produced the possibility of them listening to music. A student in the circle who was 'not following the proposal', making street dance movements, was not reprimanded. He was producing something else, being connected to his body and reacting to what had been proposed in the class in his own way. This moment was described in the research's field log as follows: 'There is life' in this class. Maybe because we had no set goal, maybe because the students were creating, maybe because there were no mechanical movements, or because there was joy and commitment. This could be nominated as a situation of present dancing bodies. According to Miller,

The present body is built through various strategies and differentiated procedures which have body listening as premise. It is a process that is based on perception as the propelling force of the study of movement and, in my view, no less a technical process. (Miller 2012, 49)

The strategies and procedures evoked by Miller compose a 'somatic technology': a dynamic form, that produces a type of no rigid limit, a type of idea-form. In somatic education, limits are built through body listening operations. The operations associated 
with this limit are akin to a technology in which rules are established throughout the process. It thus resembles that which Foucault calls ethics-oriented morality, in which rules are rudimentary or non-existent. In this way, emerges the need for an ethics that, according to Deleuze $(1992,125)$, is '[...] a set of optional rules that assess what we do, what we say, in relation to the ways of existing involved'. Hence the idea of listening as ethics, and the idea of dance teaching based on somatic principles, structured by a morality focused on ethics rather than on the code.

In addition, if in the discipline, rules are established by the norm, in the somatic perspective, normalisation is questioned. In a conference, dance teacher and choreographer Angel Vianna, refers to all of us, human beings, as 'us, pseudo-normals', emphasising the fictionality of the norm. The somatic perspective takes into account precisely the observation of singularities and impermanences of the body.

These body listening practices are, therefore, akin to a technology that produces subjects of a particular type, different from the disciplined type. If disciplined subjects are disturbed by uncertainties - by the lack of a clear result, by the ability to subvert what has been programmed - this other type of subjects constitute themselves in uncertainty, in situations where the outcome is not given. They are able to take risks because they trust and feel safe in this space of uncertainty, because within it, there is an ethics of care, which is gently, subtly and riskily maintained by everyone's listening. A mode of existence.

This, however, does not mean that discipline is not evoked at various times. At certain moments, Samara resorts to the gratification-punishment double system of discipline (for example, when choosing those who are following the rules), as well as to examination strategies, which classify students in relation to their behaviour (for example, putting or removing a star next to the child's name in the evaluation diary). There is an oscillation between disciplinary conducts and body listening conducts.

\section{Conclusions}

We challenged ourselves to identify the conditions that produce the difficulty of establishing dance practices from the perspective of somatic education in South Brazilian schools. Through an analysis based on Foucauldian studies, we recognised that there is a rejection of somatic education knowledge as an effect of disciplinary discourse. The control of bodies by discipline, which operates through observation and normalisation, excludes the first-person perception of the body and the attitude of listening.

This exclusion became clear in the difference between the silent body and the disciplined body that is established by the state of listening, as well as in the difference between the subject who accuses and the subject who senses oneself. Based on this, we identified different trends of production of the subject's body in these different modes of conducting the lessons: the disciplined body and the soma. Often, students fail to put their attention on their own bodies and on the issues being worked on by the teacher, because they are concerned with controlling others by surveillance. These students promote a constant complaint to the teacher, accusing others of being disturbing, while is precisely the accusation which is disturbing in itself.

Finally, we have observed that the dance teacher's conduct is closer to an ethics-oriented morality than to a code-oriented morality. The teacher's state of listening generates a conduct, referred to here as artistic conduct, which makes it possible to arrange dance 
practices consisting of uncertainty with school knowledge and technologies. From this conduct, the dance practice is constituted as government technology - that is, as idea-form -, seeking to produce subjects whose moralities are ethics-oriented. More than following the code, teacher Samara seeks for a state of dance which implies a connection with one's own body and with the body of one's peers. As we have seen, the disciplined body does not reach a listening state because this is not possible under surveillance, thus under disciplinary control. Through problematising dance at school, school is problematised itself.

\section{Notes}

1. In 1998, the Brazilian National Curricular Parameters are created, indicating dance, the visual arts, theatre and music as the languages of the mandatory Arts subject. However, only in 2016 Law 13,278/16 was published, establishing this mandatory character. The previous law determined as mandatory the teaching of arts in a more comprehensive sense.

2. The mapping of the research subjects identified twenty-two teachers who majored in Dance working in state schools of Rio Grande do Sul (state in southern Brazil), in the Arts subject. This means less than $1 \%$ of schools in the state.

3. Foucault presents the school as a disciplinary institution built for the production of disciplined subjects. The author describes the operations of disciplinary technology: hierarchical observation, normalising judgment, and the examination. Foucault shows that in disciplinary technology the code is constituted by the norm, it is a code of normalisation. (Foucault 2003). The author explains the procedure of disciplinary normalisation: 'there is a originally prescriptive character of the norm and the determination and the identification of the normal and the abnormal becomes possible in relation to this posited norm.' (Foucault 2009, 57). The school educates disciplined subjects, controlling their mobility to follow the norm. Then, when dance proposes disassociating from the norm, tension arises.

4. The school, a disciplinary apparatus addressed in Discipline and Punish (Foucault 2004), is, among other things, a viewing machine (Larrosa 2002, 61). It is one of the devices for 'making visible' those captured by it, in the case of schools: making children visible, to 'assign effectiveness' to the teaching process.

5. Julio Aquino (2011) problematises studies which consider students' silence and immobility as a criterion to measure 'degree of discipline' for a 'good education'.

6. The head-tail relationship is the connection between the first vertebra of the spine and the coccyx, one of the Bony Connections that, associated with the Flows of Movement and with Core Muscle Support, 'form the basis for the implementation of the Bartenieff Fundamentals' (Fernandes 2002, 51).

\section{Disclosure statement}

We declare that there is no conflict of interest with $\mathrm{CNPq}$ regarding this publication.

\section{Funding}

This work was supported by CNPq under Grant 307386/2019-8;Conselho Nacional de Desenvolvimento Científico e Tecnológico [307386/2019-8];

\section{Notes on contributors}

Maria Fonseca Falkembach is a lecturer in the Undergraduate Course of Dance Education at Universidade Federal de Pelotas, Brazil. She has a Bachelor's Degree in Performing Arts from 
Universidade Federal do Rio Grande do Sul (2001), a Master's Degree in Theatre from Universidade do Estado de Santa Catarina (2005) and a Doctorate Degree in Education from Universidade Federal do Rio Grande do Sul (2017). She has published articles and a book about dance education. Her research interests include dance education, body and movement studies, body dramaturgy, performance studies, dance-theatre. She has artistic production as a dancer, actress, and choreographer.

Gilberto Icle (BA in Performing Arts, MA in Education, and PhD in Education from Universidade Federal do Rio Grande do Sul, Brazil) has been an associate professor at the Department of Curriculum and Teaching and permanent professor of the Graduate Program in Education at Universidade Federal do Rio Grande do Sul since 2006. He did a Postdoctoral internship at Université Paris 8 Vincennes Saint-Denis (2010-2011) and a Postdoctoral internship at Université la Sorbonne Nouvelle Paris III (2017-2018). He is a collaborating professor at the Graduate Program in Performing Arts at Universidade de Brasília. He is editor-in-chief of Revista Brasileira de Estudos da Presença (www.seer.ufrgs.br/presenca). He has experience in the field of Arts (Theatre and Dance), with emphasis on Theatre Pedagogy and Performance Pedagogy, working mainly with the following themes: theatre, education, work of the actor, theatrical pedagogy, speech, performance, and ethnoscenology. He has published articles and books on theatre, and has education and artistic production as an actor and theatre director. He has a Productivity Scholarship level 1-D from the National Council of Scientific Research. He is a member of The International Federation for Theatre Research.

\section{ORCID}

Maria Fonseca Falkembach (D) http://orcid.org/0000-0002-5647-4825

Gilberto Icle (D) http://orcid.org/0000-0001-7961-4782

\section{References}

Aquino, J. G. 2011. ““Da (Contra) Normatividade do Cotidiano Escolar: Problematizando Discursos Sobre a Indisciplina Discente." [On the (Counter-)normative Spectrum of Everyday School Life: An Analysis of the Disciplinary Events of a Public School.]." Cadernos De Pesquisa 41 (143): 456-484. doi:10.1590/S0100-15742011000200007.

Berg, T. 2015. "The Pedagogy of the Observed: How Does Surveillance Technology Influence Dance Studio Education?" Research in Dance Education 16 (3): 230-244. doi:10.1080/ 14647893.2015.1019446.

Castro, E. 2009. Vocabulário de Foucault: um percurso pelos seus temas, conceitos e autores. [Vocabulary of Foucault: A Journey through Its Themes, Concepts and Authors]. Belo Horizonte: Autêntica.

Cazé, A., and J. O. Flávia 2014. "Dança Salvador: mapeando o ensino da dança na rede municipal de ensino de Salvador/BA.” [Dance Salvador: Mapping the Dance Teaching in the Municipal Teaching Network of Salvador/BA].” MA diss., Universidade Federal da Bahia.

Corrêa, J., and V. B. D. Santos. 2020. "Professoras de dança na escola pública do RS: a apropriação docente como modo de invenção e resistência." [Dance Teachers in Rio Grande do Sul State Schools: Teacher Adaptation as a Form of Creativity and Resistance.]." Iaçá Artes Da Cena 3 (1): 13-24. Accessed 20 March 2020. https://periodicos.unifap.br/index.php/iaca/article/view/5187/ 2547

Deleuze, G. 1988. Foucault. São Paulo: Brasiliense.

Deleuze, G. 1992. Conversações. [Conversations]. Rio de Janeiro: Ed. 34.

Falkembach, M., and G. Icle. 2016. “"Três Tecnologias De Subjetivação Para Pensar O Ensino De Dança Na Escola." [Three Subjectivation Technologies to Think Dance Education in Schools.]." Educação Temática Digital 18 (3): 628-650. doi:10.20396/etd.v18i3.8642170. 
Fernandes, C. 2002. O Corpo em Movimento: o sistema Laba/Bartenieff na formação e pesquisa em artes cênicas. [The Body in Motion: Laban/Bartenieff Movement Analysis in Performing Arts Education and Research.]. São Paulo: Annablume.

Fernandes, C. 2015. "When Whole(ness) Is More than the Sum of the Parts: Somatics as Contemporary Epistemological Field.” Revista Brasileira De Estudos Da Presença 5 (1): 9-38. doi:10.1590/2237-266047585.

Fischer, R. M. B. 2001. "Foucault e a análise do discurso em educação." [Foucault and Analysis of Discourse on Educational Researches.]." Cadernos De Pesquisa 114: 197-223. doi:10.1590/ S0100-15742001000300009.

Fortin, S., W. Long, and M. Lord. 2002. "Three Voices: Researching How Somatic Education Informs Contemporary Dance Technique Classes." Research in Dance Education 3 (2): 155-179. doi:10.1080/1464789022000034712.

Fortin, S., A. Vieira, and M. Tremblay. 2009. "The Experience of Discourses in Dance and Somatics." Journal of Dance and Somatic Practices 1 (1): 47-64. doi:10.1080/ 1464789022000034712.

Foucault, M. 1972. The Archaeology of Knowledge and the Discourse on Language. New York: Pantheon Books.

Foucault, M. 1998. História da sexualidade 2: o uso dos prazeres. [The History of Sexuality V. 2: The Use of Pleasure]. Rio de Janeiro: Graal.

Foucault, M. 2003. Society Must Be Defended: Lectures at the College de France, 1975-1976. New York: Picador.

Foucault, M. 2004. "Vigiar e Punir: história da violência nas prisões." [Discipline and Punish.]. Petrópolis: Vozes.

Foucault, M. 2009. Security, Territory, Population: Lectures at the College de France, 1977-78. New York: Palgrave Macmillan.

Foucault, M. 2010. "O Sujeito e o Poder." [The Subject and Power.]." In Michel Foucault uma Trajetória Filosófica: para além do estruturalismo e da hermenêutica, edited by H. Dreyfus and P. Rabinow, 273-295. Rio de Janeiro: Forense Universitária.

Garcia, Maria Manuela Alves. 2001. The emancipated subject in the critical pedagogies. Educação \& Realidade 26 (2): 31-50. Accessed Mar 20, 2020. https://seer.ufrgs.br/educacaoerealidade/ article/view/26137/15252

Gehres, A. D. F. 2008. Corpo-Dança-Educação: na contemporaneidade ou na construção de corpos fractais. [Body-dance-education: In Contemporaneity or in the Construction of Fractal Bodies]. Lisboa: Instituto Piaget.

Green, J. 2002. "Somatic Knowledge: The Body as Content and Methodology in Dance Education." Journal of Dance Education 2 (4): 114-118. doi:10.1080/15290824.2002.10387219.

Hanna, T. 1991. "What Is Somatics." Journal of Behavioral Opiometry 2 (2): 31-35. Accessed 24 April 2017. http://www.drupal.oepf.org/journal/jbo-volume-2-issue-2.

Larrosa, J. 2002. “Tecnologias do Eu e Educação.” [Technologies of the Self and Education.].” In O Sujeito da Educação: estudos foucaultianos, edited by T. T. da Silva, 35-86. Petrópolis: Editora Vozes.

Maçaneiro, S. M. 2008. "Pedagogia Crítica aplicada à dança no ensino fundamental.” [Critical Pedagogy Applied to Dance in the School].” MA diss., Universidade Federal da Bahia.

Miller, J. 2007. A Escuta do Corpo: Sistematização da Técnica de Klauss Vianna. [The Listening of the Body: Klauss Vianna's Technique]. São Paulo: Summus.

Miller, J. 2012. Qual é O Corpo Que Dança? Dança e Educação Somática Para Adultos e Crianças. [What Is the Body that Dances? Dance and Somatic Education for Adults and Children]. São Paulo: Summus.

Pineau, E. L. 2002. "Critical Performative Pedagogy: Fleshing Out the Politics of Liberatory Education.” In Teaching Performance Studies, edited by N. Stucky and C. Wimmer, 41-54. Southern Illinois University Press.

Rita, D. 2016. "Transcription of Classes and Interviews." Unpublished private archive. $82 \mathrm{f}$. 
Rosa, T. N. D. 2016. “O Termo ‘Educação Somática’ Perspectivado Pela Criação Em Dança No Brasil." [The Term "Somatic Education" from the Dance Creation in Brazil Perspective]." In Caderno Do GIPE-CIT 20 (36): 86-104, edited by A. P. Vieira and D. Becker.

Samara, D. 2016. "Transcription of Classes and Interviews." Unpublished private archive. $98 \mathrm{f}$. Souza, A. B. D. 2015. "Narrativas Sobre O Ensino Da Dança: Caminhos Tramados E Traçados Em Escolas Do Rio Grande Do Sul." [Narratives about the Dance Teaching]." PhD diss., Universidade Federal do Rio Grande do Sul. 